Letrônica, Porto Alegre, v. 7, n. 1, p. 401-419, jan./jun., 2014

\title{
IDENTIDADES: FIOS DA MEMÓRIA NO LABIRINTO CONTEMPORÂNEO
}

\section{IDENTITIES: THREADS OF MEMORY IN THE CONTEMPORARY LABYRINTH}

\author{
Mairim Linck Piva* \\ Márcia Regina da Silva Quintanilha Veras*
}

\begin{abstract}
Resumo: 0 presente trabalho, vinculado ao grupo de pesquisa "Crítica e imaginário na literatura sul-rio-grandense", analisa o romance Onde andará Dulce Veiga?, de Caio Fernando Abreu, sob a perspectiva da construção narrativa que traduz a trajetória do herói, em uma dimensão simbólica. A análise faz uma releitura do mito do Labirinto, aproximando-o da peregrinação do protagonista em sua trajetória labiríntica por uma metrópole brasileira. A análise demonstra como a obra contemporânea, em suasmúltiplas configurações, traduz os passos da "aventura do herói", assim como identifica na obra imagens que desvelam a busca do sujeito contemporâneo por uma noção de identidade através da tentativa de recuperação da memória.
\end{abstract}

Palavras-chave: Imaginário; Memória; Labirinto; Trajetória do herói; Caio Fernando Abreu.

\begin{abstract}
The present work is related to the research group "Crítica e imaginário na literature sul-rio-grandense". This article analyses the novel Onde andará Dulce Veiga? By Caio Fernando Abreu on the perspective of the narrative's construction which translates the hero's trajectory, in a symbolic dimension. The analysis is a rereading of the labyrinth myth, showing the main character's pilgrimagein his labyrinthine path in a Brazilian metropolis. The analysis shows how the contemporarywork in its symbolic construction, represents the paths of the hero's adventure, as well as identifying in the work the images that unveil the contemporary subject searching for the notion of identity through the recuperation of the memories.
\end{abstract}

Keywords: Imaginary; Memory; Labyrinth; Hero's trajectory; Caio Fernando Abreu.

A experiência urbana moderna é analisada em diversos estudos que descortinam um modo de vida instável, pleno de incertezas, que, inúmeras vezes, conduz ao estilhaçamento das identidades As cidades contemporâneas são, como afirma Maria

\footnotetext{
* Doutora em Teoria Literária (PUCRS), professora Adjunta de Literatura do Instituto de Letras e Artes (ILA) da Universidade Federal do Rio Grande (FURG), coordenadora do GP "Literatura, Imaginário e Poéticas da Contemporaneidade", coordenadora do Projeto de pesquisa, apoiado pelo CNPq e FAPERGS, "Crítica e Imaginário na literatura sul-rio-grandense".

* Pesquisadora do Projeto de pesquisa, apoiado pelo CNPq e FAPERGS, "Crítica e Imaginário na literatura sul-rio-grandense". Bolsista CNPq 2012, bolsista FAPERGS 2013-2014.
} 
Bernadete Porto, "um convite para nossas próprias desleituras identitárias" (PORTO, 2010, p.71).

Do ponto de vista econômico, as certezas e as verdades da existência contemporânea foram diluídas na "mão invisível" da "acumulação flexível"1, em que o espaço e o tempo formaram um novo arranjo, pelo qual nem sempre é permitido ao indivíduo ser o autor de sua própria biografia. 0 indivíduo torna-se um nômade em um mundo sem fronteiras, podendo cruzar barreiras espaciais e temporais sem limites, sem ater-se a raízes.Do ponto de vista da subjetividade, essa errância pela vida, sem conexões com espaços específicos ou com vínculos afetivos duradouros, pode apontar para a perda da noção de abrigo seguro, de marcas identitárias socioafetivas, trazendo à tona uma constante sensação de incompletude.

Aoter descortinadas suas fragilidades, o ser humano volta-se para muitas instâncias, como se orientar para "templos" de consumo ou de entretenimento dos espaços urbanos, que nem sempre apontam os caminhos da saciedade ou de uma pretensa integralidade. A arte é outra das instâncias sempre presente na busca humana por respostas a suas necessidades de compreensão e de afirmação no seu processo de individuação. Na ficção brasileira contemporânea, diversos autores retratam o universo urbano como desintegrador e caótico, com cidades representadas como local de contradições e conflitos, onde a fluidez econômica ou arquitetônica projeta-se nas relações humanas que se tornam tênues e instáveis.

A obra romanesca Onde andará Dulce Veiga?, do escritor sul-rio-grandense Caio Fernando Abreu, foi publicada em 1990. O romance narra a história de um jornalista desempregado e solitário no início dos anos 80 que, em face a uma crise identitária, profissional e amorosa, encontra-se em um estado de profundo vazio existencial. Isolado do mundo, em seu apartamento, recebe uma proposta de emprego que enseja na busca

\footnotetext{
1 Mão invisível do mercado, expressão do economista Adam Smith, em Riqueza das Nações (1776), para designar o equilíbrio entre a oferta e a procura nos mercados capitalistas, reforçando a crença no individualismo como virtude competitiva necessária à eficiência dos mercados. Acumulação flexível, mudança no paradigma organizacional do capitalismo assinalando um regime de acumulação que começa a vigorar no fim do século XX, em que as novas tecnologias reorganizam as relações de trabalho e os sistemas de produção. Nesta face do capitalismo, predomina a mobilidade hipergeográfica do capital e do emprego, como também flexibilidade nas relações de trabalho gerando empregos precários e desemprego estrutural. As transformações em dimensões sociais, culturais e econômicas modificam a noção de espaço e tempo (HARVEY, 1998). Assim, o termo designa os efeitos desta nova forma de organização do capitalismo nas relações sociais e humanas, como algo que não é percebido de forma direta mais é incorporado ao imaginário e a trama social contemporânea.
} 
por uma cantora desaparecida, Dulce Veiga. Essa atividade investigativa o leva a uma peregrinação pelos espaços de uma metrópole brasileira, em um processo desencadeador de recuperação de memórias, de compreensão e afirmação de sua identidade.

A obra possui um vasto universo simbólico que propicia diversas hermenêuticas. 0 texto apresenta um mosaico de imagens que traduzem elementos que permeiam a vida urbana moderna como desigualdade, invisibilidade, solidão, drogas, sexo, música, violência, poluição, ecletismo religioso, temas que podem dar subsídios para uma ampla gama de análises.

O olhar sobre o romance de Caio F. Abreu gravita sobre o tema do homem urbano moderno, tomando-se o espaço urbano caótico e desorientador como um local de buscas. A narrativa sugere incertezas e descaminhos, mas estas dificuldades levam a uma trajetória de iluminação. 0 espaço urbano em que se passa a narrativa possibilita uma releitura do mito do Minotauro, aproximando a trajetória pela urbe com uma entradano labirinto mítico. Essa análise objetiva verificar se a obra contemporânea, em sua construção simbólica, traduz os passos da aventura do herói apresentados por Campbell (2004), assim como objetiva-se identificar na obra imagens não aparentes que relacionem o espaço urbano da grande metrópole, onde transcorre a narrativa, com a metáfora do labirinto do Minotauro.

Campbell (2004) define um padrão básico e imutável na narrativa mítica, pois as semelhanças contidas nas narrativas dos mitos de jornada heroica são independentes do tempo e espaço, sendo suas estruturas compostas pelos mesmos estágios que traduzem a jornada do herói. Intenta-se uma análise de Onde andará Dulce Veiga? numa perspectiva simbólica em que se retomam os dramas humanos a partir dos mitos e dos rituais iniciáticos que podem ser compreendidos dentro da teoria do imaginário, nas linhas de Gilbert Durand, Gaston Bachelard, Mircea Eliade e Joseph Campbell.

A narrativa inicia-se com a afirmação "Eu deveria cantar" (ABREU, 1993, p. 11), mas, devido à perda de vínculos amorosos que leva o protagonista ao vazio e à solidão, a personagem perde também a fé e a esperança, além da capacidade de cantar. Essa primeira frase da narrativa impõe o tom musical que embalará a trajetória do herói do começo ao fim, pois a aventura termina com a frase "E eu comecei a cantar" (ABREU, 1993, p. 213). A música representa o fio condutor desta narrativa, o fio de Ariadne que 
guia seu trajeto e iluminação, é parte referencial figurada em toda a estrutura narrativa, ajuda a construi-la assim como conduzir o herói ao centro do labirinto. É através dela que a personagem vai cumprindo suas tarefas e retomando suas memórias para finalizar as etapas do herói, todas estas ligadas à música. Para DURAND (1989, p. 155):

A música opera o milagre de tocar em nós o núcleo mais secreto, o ponto de enraizamento de todas as recordações e por fazer dele por um instante o centro do mundo feérico, comparadas a sementes enfeitiçadas, os sons ganham em nós com uma rapidez mágicanum abrir e fechar de olhos sentimos o murmúrio de um bosque semeado de flores maravilhosas.

A música embala as lembranças da infância, os amores perdidos, vincula o presente a sensações passadas. Na narrativa, o protagonista ao recuperar uma de suas lembranças reprimidas, a da personagem Pedro, retoma uma experiência amorosa essencial, um encontro de intensa vivência amorosa, como também a experiência do abandono e da solidão, tudo isso manifesto a partir da música. A música também leva o jornalista a um retorno às suas origens através das memórias do universo infantil em Passo da Guanxuma, sua cidade natal, localizada na ficção como no interior do Rio Grande do Sul.

A narrativa apresenta um universo musical eclético em que transitam os vários estilos musicais que se formam como colagens labirínticas que, em alguns momentos, levam à desorientação, mas todas essas imagens se relacionam na trajetória do herói conduzindo-o ao centro, “[...] a música desempenha um papel mediador para alargar as comunicações até os limites do divino." (CHEVALIER, 2003, p. 627).

No romance o fio musical atravessa toda a diegese, liga o herói ao passado, constrói a dimensão temporal unificando passado e futuro, numa mistura de sons que relembram o passado que se presentifica. Como exemplo, tem-se a versão musical de Nada Além, música dos anos 60, interpretada por Dulce Veiga, e regravada pela banda Vaginas Dentadas, que representa o universo underground da década de 80. Essa ligação temporal musical traz a presença do tempo mítico da morte e ressurreição; o fio liga o homem ao seu destino, "é a imagem direta das 'ligações' temporais, da condição humana ligada à consciência do tempo e à maldição da morte." (DURAND, 1989, p. 77).

A personagem no início da narrativa demonstra ter perdido a fé, a esperança e o amor, encontrando-se no pequeno espaço de seu apartamento onde se protege de suas memórias e sentimentos. Esse processo de fuga,iniciado com o fim da relação amorosa 
com Pedro, representa também o conflito frente à perda afetiva, à sexualidade e consequentemente, frente à própria identidade.Esses conflitos representam o labirinto interior, projeção dos valores inculcados pela sociedade e que se transformam em verdadeiras barreiras subjetivas que impedem a libertação, levando à fragmentação da identidade. A falta de laços afetivos gera recalcamentos e conflitos que só podem ser superados pela jornada no labirinto exterior, "o labirinto talvez esteja tanto dentro de nós, como nos dentro dele; ou, ainda, que somos nós que o projetamos para fora. De objetivo ele se faz subjetivo, ou vice-versa." (BRUNEL, 2005, p. 560).

O espaço do apartamento é seu refúgio interior, que protege o protagonista do universo exterior, "de uma cidade infernal como aquela que trepidava lá fora, além da janela fechada do apartamento" (ABREU, 1993, p.11).A casa é considerada um espaço de defesa ou de intimidade; como espaço de defesa, funciona como uma fortificação, algo que separa as regiões estranhas e, como espaço íntimo, abriga as memórias onde estão as raízes do sujeito.Conforme Durand (1989, p. 117) “a casa que abriga é sempre um abrigo que defende e protege e que se passa continuamente de sua passividade à sua actividade defensiva".

Sair deste refúgio significa o início de uma vivência de transformação em que a experiência objetiva de procura pela cantora desaparecida se transforma num ritual de iniciação que leva à purificação e à ressurreição, uma experiência subjetiva. Conforme Campbell (2004, p. 27), “a primeira tarefa do herói consiste em retirar-se da cena mundana dos efeitos secundários e iniciar uma jornada pelas regiões causais da psique, onde residem efetivamente as dificuldades, para torná-las claras, erradicá-las em favor de si mesmo".

A etapa da partida inicia-se com o 'chamado aventura', que, segundo Campbell (2004, p.60), pode "anunciar o chamado para algum empreendimento histórico, assim como pode marcar a alvorada da iluminação religiosa. [...] marca aquilo que se deu o nome de 'o despertar do eu'. [...] descerra as cortinas de mistério de transfiguração- um ritual, ou momento de passagem espiritual que, quando completo, equivale a uma morte seguida de um nascimento".

Este chamado pode vir através de um 'arauto', algo mágico que convida o herói à aventura. Na narrativa, um telefonema é o arauto, uma voz que relembra o passado: "Espantoso, na noite anterior eu fora dormir como um jornalista desempregado, 
endividado, amargo, solitário e desiludido e magicamente aquela voz do passado me comunicando que eu era da pesada" (ABREU, 1993, p. 13). A ligação telefônica, com oferta de um emprego, representa a saída da vida de desempregado, sem identidade, sem nome,impulsionando a personagem para um movimento em direção ao desconhecido, em busca de si, a procurar no exterior a integridade interior, a harmonização, fruto do enfrentamento. Para chegar ao centro do seu labirinto interior é preciso percorrer o labirinto da cidade; Bachelard (1993, p. 26) aponta nesse processo uma saída psicanalítica: "a psicanálise convida o ser a viver fora dos abrigos do inconsciente, a entrar nas aventuras da vida, a sair de si [...] dar um destino exterior ao ser interior".

A proposta de emprego leva o indivíduo ao movimento, é o sopro suave e uma energia vital, "nada muito sensacional", um milagre, o arauto. "Pense nesse milagre, homem. Singelo, quase insignificante na sua simplicidade, o pequeno milagre capaz de trazer alguma paz àquela série de solavancos sem rumo nem ritmo... minha vida." (ABREU, 1993, p. 12).

0 processo de passagem é acompanhado pelo fio musical; enquanto a personagem toma um banho para iniciar o seu primeiro dia de trabalho, a música inicia o processo de reconduzi-lo à retomada da memória: "Então ouvi no rádio uma música que parecia conhecida, 'a realidade não importa o que importa é a ilusão, no que eu concordava plenamente. Pelo menos nos últimos meses, não me acontecera nada além de fantasias. Mas a música que ressoava em algum porão da memória era antiga" (ABREU, 1993, p. 13).

Após o convite do emprego, o herói é transportado para um novo limiar, inicia-se o ritual de iniciação em que "o herói caminha por uma passagem onírica povoada por formas curiosamente fluidas e ambíguas na qual deve sobreviver a uma sucessão de provas" (CAMPBELL, 2004, p. 102). Este espaço onírico é representado no romance por uma grande metrópole, São Paulo, o labirinto das provas, cujamissão jornalística levao protagonista a por ele transitar, cumprindo as provas que fazem parte da trajetória do herói.

Neste espaço estão presentes os dramas existenciais do homem urbano que são discutidos em obras de diversos autores que analisam esta questão, como Zygmunt 
Bauman, que relata a falta de confiança e o medo que imperam nas cidades, levando à solidão e à falta de laços comunitários.

A modernidade que poderia representar a promessa de um avanço em direção à liberdade, tomou um rumo oposto, em direção ao sufocamento labiríntico. A solidão e o medo são sentimentos que modelam modernamente a conduta humana, se transformam em um sentimento coletivo. (BAUMAN, 2008). A sensação de solidão na multidão, de não pertencimento é um sentimento partilhado pelo ser moderno. Para reconstruir a ordem tomada pelo caos moderno e conviver toleravelmente com estes sentimentos conflitantes e destruidores, busca-se a memória para reorganizar o descontínuo. As memórias, os laços, o afago maternal da infância dá a estabilidade àidentidade. No romance, os atalhos propiciados pela evocação das memórias também restabelecem na personagem descrente e sem fé o reencontro com o sagrado.

O espaço urbano moderno é descrito em diversos textos como um labirinto, como uma saturação de elementos capazes de desnortearem o sujeito que o habita: "as cidades convocam todos os sentidos: com seus cheiros, barulhos e apelos visuais elas existem como corpo pulsante que podemos tocar - ainda que sob o signo do provisório e do fragmentado" (PORTO, 2010, p.71). M. Berman aponta que aventura da modernidade, marcada pela sensação do descontínuo que gera uma desacomodação identitária dentro do turbilhão de mudanças que risca da história as tradições, impõe novos ritmos de tempo e cria novas noções espaciais. Para o autor, "essa atmosfera - de agitação e turbulência, aturdimento psíquico e embriaguez, expansão das possibilidades de experiência e destruição de barreiras morais e dos compromissos pessoais, autoexpansão e autodesordem, fantasmas na rua e na alma - é a atmosfera que dá origem à sensibilidade moderna". (BERMAN, 1986, p. 18)

A agitação e a turbulência urbana provocam no indivíduo o desconforto e ansiedade, o "arquétipo do caos" causa repugnância e a cidade simboliza para o indivíduo o inferno, com aponta Durand (1989, p. 54):

O inferno é sempre imaginado pela iconografia como lugar caótico e agitado [...] o esquema de animação acelerada que é a agitação formigante, fervilhante ou caótica parece ser uma projecção assimiladora da angústia diante da mudança […] e a adaptação que ela motiva é a primeira experiência do tempo.

As constelações simbólicas que compõe o universo urbano moderno gravitam em torno do símbolo do labirinto, algo que absorve o indivíduo, visto como um aparelho 
digestivo triturador. No romance de Caio Fernando Abreu ocorre o duplo, a inversão, o labirinto e seus caminhos tortuosos levam a personagem à redenção, à descida dentro de si, à busca do centro. O labirinto dissolve-se no encontro com o Minotauro, que representa os medos e memórias mais profundas do ser humano. 0 Minotauro é a parte não aceita, o que causa temor, nojo, é este medo fortuito, invisível e mascarado que representa o anseio interior que a sociedade, na sua expressão material e simbólica, a cidade, nega. É "o monstro que cada homem arrasta consigo e enfrenta, [...] tempo que tudo devora, paixões e desejos com que cada um se debate, [...] o que há de negativo no homem". (FERREIRA, 2008, p. 46).

$\mathrm{Na}$ obra, o labirinto aparece de forma explícita na forma da construção da narrativa; de forma metafórica na representação da cidade adaptada à leitura do mito do Minotauro; e no interior da personagem, marcado pelos conflitos perante a sexualidade, a identidade e a repressão das memórias. Todas essas formas interligadas constroem a trama semântica do labirinto.

A figura labiríntica aparece explicitamente no romance nomeando o capítulo V: Labirinto de Mercúrio. Neste capítulo, a personagem descreve um sonho com o labirinto:

De cima, de longe. No terraço de um edifício, na beira de um viaduto, à bordo de um avião, nada é claro, eu olho para baixo, para o centro de que parece um labirinto, uma elipse. Círculos concêntricos, movediços, devoradores. Alguém me empurra pelas as costas, eu tento inutilmente segurar em alguma coisa. [...] É mais seguro permanecer aqui. [...] Eu caio girando no espaço. [...] Acordei antes de tocar na terra. (ABREU, 1993, p. 171).

O universo onírico da personagem demonstra o medo do labirinto urbano que absorve o indivíduo, como também o conflito interior e o medo de entrar no universo de suas memórias. A personagem percebe a cidade como um labirinto devorador, na qual uma força invisível o empurra para dentro. Durand (1989) relaciona a imagem labiríntica com a cavidade, ventre ou esgoto onde estão presentes as imagens repugnantes, local de assombro, imagens digestivas e carnais. Um labirinto vivo, animado, lugar do pecado vinculado ao princípio do prazer. Esta imagem remete ao conflito da personagem frente à sexualidade e ao resgate do amor e da identidade perdida. Além disso, o labirinto pode também ser um desencadeador psicológico e moral que leva ao heroísmo da ascensão.

Nos espaços da cidade percorridos pela personagem, aparecem as diferentes formas do prazer nas figuras de prostitutas, homossexuais, mixes, que constroem o 
universo do prazer proibido, reprimido socialmente. Essas figurações traduzem a diversidade e complexidade da imagem labiríntica do prazer, nas suas diversas formas sem laços afetivos, imerso no universo de fuga no álcool e nas drogas.

A segunda descrição do labirinto, no capítulo $\mathrm{V}$, remete a um jogo que, diferente do universo onírico, a personagem pode controlar, tornar-se sujeito ativo de sua transformação.

Era um jogo. Um labirinto em forma de hexágono, sobre um fundo preto, com uma gota prateada de mercúrio do lado de fora do labirinto, tudo coberto por acrílico transparente. Virei-o nas mãos, a gota de mercúrio bateu contra uma das paredes e partiu-se em três. Tornei a virá-lo, mais devagar. Uma das gotas partidas entrou no labirinto. Com movimentos cada vez mais suaves consegui que ela começasse a deslizar pelos corredores, em direção ao centro. Das duas gotas que ficaram de fora, uma partiu-se em mais duas, outra entrou também pelo labirinto, escorregou a encontro daquela que já estava lá dentro e fundiuse nela. [...] você tem que colocar a gota inteira bem no centro sem deixar que ela se parta. (ABREU, 1993, p. 173).

A integração da identidade ocorre como um processo alcançado através da superação das dificuldades da vida. A gota de mercúrio, metal líquido e volátil, que se divide, é a metáfora da identidade fragmentada da personagem dissolvida no labirinto urbano de ligações tênues, representando o sentimento de vulnerabilidade, de dissociação no espaço, cabendo, no entanto, àpersonagem o encontro com o centro.

Só e submisso, perdido no centro deste cruzamento confuso, no meio do terror de não ser mais capaz, sem nada nem ninguém que pudesse vir em meu socorro, além da própria coisa em si, e ela mesmo traiçoeira, talvez assassina, escorregadia feito serpente, ainda e talvez para sempre informe, porque eu, o único capaz de aprendê-la poderia deixá-la fugir. (ABREU, 1993, p. 54).

Na mitologia, mercúrio possui diferentes variações de sentido como fecundação espiritual, função de intermediário, e condutor de alma, podendo significar o auxílio na compreensão da vida espiritual. Hermes (Mercúrio) configura-se na modernidade como mensageiro que aprofunda os caminhos para busca interior, no momento de barbárie do ocidente (BRUNEL, 2005). Em sua jornada,um herói recebe sempre a ajuda de uma força sobrenatural, "grande figura do guia [...] Hermes - Mercúrio [...] ele é o condutor do espírito inocente para o reino da provação". (ELIADE, 2002, p. 77).

O universo urbano representado na narrativa pelo jogo Labirinto de Mercúrio, está também presente no tecido textual que constrói através do jogo de imagens contidas nas palavras o universo labiríntico das grandes metrópoles. É preciso abstrair da cidade a sua simbologia labiríntica composta por fragmentos de estilos, sons 
desorientadores, diversos cheiros, arquitetura que sobrepõe uma colagem de estilos e que se organizam em vários planos, e um entrecruzamento de existências. Para Gomes (2008, p. 24) o texto relata uma forma de ver a cidade, possibilita absorvê-la em sua sensibilidade "não enquanto mera descrição física, é mais como cidade simbólica, que cruza lugar e metáfora, produzindo uma cartografia dinâmica, tensão entre racionalidade geometria e um emaranhado de existências humanas."

A cidade de São Paulo construída enquanto discurso possibilita visões que se estruturam a partir do universo simbólico presente no texto literário. 0 universo caótico urbano impõe às palavras um desprendimento maior, a linguagem não se constrói de forma linear com mera descrição, ela transita em vários planos. 0 excesso de imagens não permite uma linguagem sucinta, ela se expressa no excesso de palavras, na abundância de palavras se prende à transitoriedade e à desorientação. Como exemplo, tem-se a descrição da cidade em pedaços, fragmentos: "o ar azedo do bar do jornal, em frente aqueles vidros redondos atulhados de ovos de cascas azuis" (ABREU, 1993, p.59), "O asfalto molhado da Ipiranga era um fio de luzes refletidas, invertendo os edifícios." (ABREU, 1993, p. 66). "Britadeiras vibravam no prédio em construção em frente ao Quênia's Bar, ao lado da funerária. Nordestinos quase nus, carrinhos de mão, pedras, suspensos nos andaimes, formigas fervilhantes numa longa fila, do Cariri à estação da Luz." (ABREU, 1993, p. 81).

A cidade também se presentifica no não dito, no desejo apenas, um simulacro que traduz a vontade de estar invisível, sair deste labirinto. A cidade no texto é construída em cifras desprendidas de sensações e imagens descritas pela personagem neste espaço: acordes horripilantes, fumaça de cigarro, Gilette batendo no vidro, latas vazias e folhas de jornal pelas ruas, marquises metálicas, apartamento vazio, sirenes de ambulância, edifício doente. Todas essas imagens espalhadas no texto compõem o universo desorientador que a metrópole moderna fomenta, possibilitando a metáfora labiríntica. Assim, para Brunel (2005, p. 556) "O labirinto é antes de mais nada uma imagem mental, uma figura simbólica que não remete a nenhuma arquitetura exemplar, uma metáfora sem referente."

Ler a cidade como estrutura labiríntica na narrativa transfere à cidade a função do labirinto, como espaço desorientador, que permite uma viagem iniciatória pela dificuldade no percurso onde estão presentes os entrecruzamentos de caminhos e que 
leva o iniciado a ter que fazer escolhas que se constituem em impasses, sendo que, resolvê-los, possibilita o aprendizado para penetrar no centro (BRUNEL, 2005).

A cidade em Onde andará Dulce Veiga pode ser lida como um mosaico de imagens ou também um excesso de imagens que a personagem descreve ao percorrer as ruas da cidade "fumaça, hálito, suor evaporado, monóxido, vírus" (ABREU, 1993). Esses elementos traduzem a sensação labiríntica de desorientação no excesso e no caos em que a imagem simbólica é construída por fragmentos. Diversas são as configurações dos universos urbanos percorridos, como a Mansão de Rafik (dono do jornal), o prédio do protagonista descrito como um edifício doente, com rachaduras como feridas, a casa de Márcia Felácio um cantinho bucólico no subúrbio, como também as figuras disformes que são encontradas na multidão da cidade:

passei por dois anões, um corcunda, três cegos, quatro mancos, um homem tronco, outro maneta, mais um enrolado em trapos como leproso, uma negra sangrando, um velho de muletas, duas gêmeas mongolóides, de braço dados, e tantos mendigos que não consegui contar.A cenografia eram sacos de lixo com cheiro doce, moscas esvoaçando, crianças em volta. (ABREU, 1993, p. 21).

A personagem, assim como o herói Teseu, percorre o labirinto urbano onde ocorrem as provas, tarefas que o herói tem que cumprir para chegar à iluminação. A cada tarefa que o jornalista vai cumprindo pela cidade, percorrendo seus caminhos, vai se construindo a imagem labiríntica, e o aproximando de Dulce, do resgate de suas memórias reprimidas e da redescoberta de si mesmo.

A redação do jornal onde a personagem recebe a primeira tarefa de sua jornada é também um local labiríntico povoado pelo excesso de objetos e imagens desorganizados que se perdem no todo "cinzeiros perdidos entre pilhas de laudas, fotos, clips, pastas, envelopes, copo de plástico, adoçante artificial, tubos de cola, rolos de dinheiro, bilhetes de loteria, blocos, lápis, canetas, restos de sanduíche, latas de coca-cola diet" (ABREU, 1993, p. 14). Naquele caos de imagens o olhar foca em objetos que ecoam em algum espaço da memória e evocam uma sensação de desconforto perante as lembranças: "Aquele cinzeiro, eu também achava que conhecia [...]. Na verdade, uma por uma daquelas bugigangas pareciam familiares. E isso não era exatamente o que eu chamaria de 'uma sensação agradável”. (ABREU, 1993, p. 14).

Inicia-se o caminho das provas e sua primeira missão a ser cumprida como jornalista está diretamente ligada à música: entrevistar Márcia vocalista da banda 
underground "Márcia Felácio e as Vaginas Dentadas". O herói atravessa o espaço urbano caótico, uma multidão disforme, um trânsito confuso onde o carro se arrasta no calor que sufoca. No caminho encontra com mensageiros que lhe trazem presságios de boa sorte:

\begin{abstract}
Na esquina estava um homem vestido com um macacão alpino, de chapeuzinho verde, tocando realejo para um periquito desses que tiram a sorte. Parei. 0 homem fez o periquito bicar três vezes o papelzinho antes de estendê-lo para mim: 'o habito de trabalhar proporcionar-te-á todas as comodidades da vida: aprende a ser feliz em um honesto viver, desejas notícias que serás surpreendido com uma fortuna de que viverás feliz, eis o que teu signo diz."(ABREU, 1993, p. 21).
\end{abstract}

Do caos urbano ao caos musical, o protagonista mergulha em "uma gritaria infernal. Um assassinato, uma tourada, festa de criança ou estupro. It'sonly rock androll, pensei" (ABREU, 1993, p. 18). A cenografia da banda retrata a urbanidade caótica: “Troncos, cabeças. Pouco depois, ao fundo, um cenário de papelão pintado reproduzindo edifícios em ruínas cercados de enormes latas de lixo [...]" (ABREU, 1993. p. 25). Coberto pela névoa ofuscante de gelo seco, o local sombrio, barulhento, em que as imagens e sons se confundem,desorientam indivíduo. As trevas e o barulho são símbolos negativos, ligados à angústia, ao medo, e à depressão, ao caos, compondo o local onde se vaga. Mas não existe luz sem a trajetória pelas trevas, e opostos aos símbolos tenebrosos estão os símbolos ligados à luz (DURAND, 1989). O processo de iluminação é precedido pelos caminhos das trevas e neste local simbólico das trevas surge através da música uma fagulha de luz. A música "desempenha um papel mediador para alargar as comunicações até o limite do divino". (CHEVALIER, 2003, p. 627).

A música tocada pela banda Vaginas Dentadas permite à personagem entrar em contato com sentimentos e emoções: saudade, desgosto, medo e pena, um sentimento sem referência que aos poucos é desvelado por imagens na memória: sala escura com janelas cerradas com cortinas, cinzeiro antigo, poltrona de veludo verde. As sensações e imagens passadas conduzem a um flash, Dulce Veiga. Esse contato com suas emoções permite ao indivíduo resgatar os seus fragmentos, buscar o ausente nos tempos vividos, buscar nesta trajetória temporal de viajante pela urbe a própria identidade.

A lembrança de Dulce indica o caminho da próxima prova, para isso é necessário percorrer o labirinto sombrio em que o herói transita sempre no lusco-fusco, penumbra urbana em meio achuva, tempestades e enchentes. "Vai cair uma tempestade [...], e 
comecei a caminhar rápido em direção ao Ibirapuera [...], antes que as ruas ficassem alagadas, intransitáveis, a cidade em estado de calamidade" (ABREU, 1993, p. 31).

Durand (1989) ressalta o aspecto tenebroso da água, aspecto ligado ao inconsciente coletivo, das memórias ancestrais dos pântanos, lodaçais, e inundações assombrosas, a epifania da desgraça. A água é o elemento que representa as lágrimas e o sentimento de incompletude. Em meio à tempestade, aparece Dulce como fragmento da memória, que se esconde nas ruas da cidade, ela reaparece em vários momentos finalizando etapas, é uma espécie de guia que aponta sempre o indicador em direção ao céu. Este gesto está ligado ao esquema da ascensão; segundo Durand (1989, p.90), "estes símbolos ascensionais são meios para atingir o céu". Opostos à queda no labirinto, esse gesto aponta a saída através do processo da iluminação, e da retomada da memória retratada na figura de Dulce.

A retomada da memória de Dulce Veiga submete a personagem a uma nova e difícil tarefa: escrever uma crônica sobre esta cantora. Antes de iniciar esta tarefa novamente recebe uma mensagem que aponta a iluminação, o disco Armagedon dado por Márcia, com a seguinte mensagem escrita na capa: "Qual o caminho para a morada da luz, e em que lugar se encontram as trevas?" (ABREU, 1993, p. 51).

Escrever significa subir mais um degrau a caminho da iluminação, se achar no labirinto das palavras no qual ele tinha se perdido, "escrever.. a gente desaprende, enferruja, entorpece" (ABREU, 1993, p. 53). Escrever é um ato de exposição, de mostrarse através das palavras, mas na verdade, assim como Dulce, o jornalista queria estar invisível, não pertencer aquele lugar: "eu queria ser invisível. Acendi outro cigarro. Letár-gi-co, assim eu andava, a-pá-ti-co, co-le-óp-te-ro" (ABREU, p. 53). A invisibilidade sugere também a necessidade de se encapsular, de buscar dentro de si o que é difícil de trazer à tona. 0 exílio perante as coisas do mundo possibilita vislumbrar novos horizontes o que leva a uma nova perspectiva frente à vida, neste caso um processo de metamorfose. "Então fechei os olhos. E comecei a me distanciar dos telefones tocando, das máquinas batendo, das vozes fragmentadas em farrapos de conversas [...] para prestar atenção somente às batidas do meu próprio coração." (ABREU, 1993, p. 54)

Após esse processo, cumprida esta etapa, Dulce aparece novamente na penumbra do fim da tarde e aponta um guarda-chuva para o céu. Como em um jogo, ela o atrai e se desmaterializa guiando seus passos e apontado o caminho. A figura feminina representa, 
segundo Campbell (2004, p. 117),"na linguagem pictórica da mitológica, a totalidade do que pode ser conhecido. 0 herói é aquele que aprende. À medida que ele progride, na lenta iniciação que é a vida, a forma da deusa passa, aos seus olhos, por uma série de transfigurações. [...]Ela o atrai e o guia e lhe pede que rompa os grilhões que o prendem".

0 jogo de procura por Dulce em meio à cidade levao protagonista a um edifício onde percebe um som de um piano: a princípio notas soltas, mas que aos poucos ressoam uma melodia que ele reconhece, tem vontade de cantar, mas suas lembranças ainda se constituem em fragmentos. 0 encontro com o ex-pianista de Dulce traz à memória o nome de Saul, a personagem que desvela o mistério do paradeiro de Dulce.

A crônica sobre Dulce leva à missão final de desvelar os mistérios do seu desaparecimento aproximando as personagens, Márcia, Saul, Pedro e Dulce. Essas personagens, assim como o jornalista, são indivíduos que vivem à margem da sociedade, representam o esfacelamento familiar, a falta de vínculos, a precariedade da vida urbana. Esses indivíduos se sentem engolidos pelo universo desorientador da cidade e procuram a fuga em prazeres fugidios como sexo e drogas. Sentem a dor do não pertencimento e lutam pela liberdade através da transgressão. As lutas quando não são solitárias, como a de Dulce que encontrou a solução no escapismo, são feitas por manifestações de grupos que se identificam através da música, da sexualidade, ou das drogas: "a opção pela afirmação de uma tal identidade de grupo é explicada como uma forma de buscar a aceitação de determinados atos e comportamentos através da ratificação subversiva dos discursos que instituíram essa verdade.” (LEAL, 2002, p.22)

A busca por Dulce encarna a lembrança de Pedro que, assim como Dulce, se desmaterializa no labirinto da cidade. No universo urbano, os objetos e as relações são tênues, nada parece fixo e tudo desaparece, é um local de perder e de se perder. Berman (1986, p. 15) aponta esse tipo de experiência como:

Experiência vital - experiência de tempo e espaço, de si mesmo e dos outros, das possibilidades e perigos da vida - é compartilhada por homens e mulheres em todo o mundo, hoje. [...] modernidade [...] ameaça a destruir tudo que temos, tudo o que sabemos, tudo que somos. [...] Ser moderno é fazer parte de um universo no qual, com diz Marx, 'tudo que é sólido desmancha no ar'. 
Márcia e o protagonista estão ligados pelos conflitosem relação à sexualidade e à saúde, pois ambos suspeitam estarem contaminados ${ }^{2}$ e apresentam dúvidas quanto à sexualidade. "- Você é homossexual? - Não sei. - Eu também não sei direito." (ABREU, 1993, p.168). A angústia, que traz a incerteza, gera a necessidade de completude no outro, ou na imersão dentro de si, olhando diretamente para seus medos tentando compreendê-los através do resgate de sua história, ou no resgate da fé perdida.

Na procura de seu lugar no mundo a personagem resgata a religiosidade perdida, inicia esta busca através dos búzios jogados por sua vizinha Jandira, que pode representar nas jornadas mitológicas a consulta ao oráculo para prever o futuro: "Meu filho, os caminhos estão muito mais abertos do que você imagina. Só que eles parecem tortos. Mas é por esses caminhos que parecem tortos que você tem que caminhar, e as coisas vêm ao seu encontro. Você só tem que escutar os caminhos e seguir por eles. Vira estrela e vai pro meio da mata, Ilê te espera". (ABREU, 1993, p. 38).

A última aparição de Dulce soma-se aos outros sinais que apontam para o fim da trajetória:

toda vestida de branco, os cabelos louros e o vestido esvoaçando na brisa da tardezinha, recortada contra a noite que vinha chegando do outro lado do mar, estava parada Dulce Veiga. Ela ergueu o braço direito no ar, a mão estava meio fechada. Quando o braço ficou completamente esticado, ela abriu a mão e soltou um pombo branco. As asas do pombo refletiram por um segundo os raios de sol [...] Depois sumiu no azul entre as gaivotas. (p. 179).

As constelações simbólicas em torno destas imagens de Dulce estão ligadas ao esquema da ascensão: a cor branca, o azul do céu, o dourado, o pombo branco, mar. Todas estas imagens convergem para o processo de purificação e iluminação e sugerem o fim do ciclo das provas. Esse ciclo se fecha com o encontro da personagem com Saul: o encontro do iniciado com seu interior desvela o que lhe causa os maiores temores, sentimentos sexuais reprimidos, que terá que enfrentar face a face. Esse encontro como o eu interior representa o encontro com o Minotauro, o monstro que habita os

\footnotetext{
${ }^{2}$ A narrativa, ao mencionar 'caroços e gânglios' sentidos pelas personagens, e referir a noções de 'contaminação' pelas relações sexuais, indicia uma referência a uma doença conhecida como "Aids". Nos anos 80, a Aids foi retratada por alguns segmentos como a "peste gay", seguindo a tendência de doenças estigmatizadas no passado como sífilis e tuberculose. Se por um lado a doença visibilizou certos preconceitos, por outro motivou reações à segregação e lutas em busca do reconhecimento da identidade homoafetiva e do respeito à alteridade.
} 
corredores escuros do inconsciente. Vencer o Minotauro é a prova final na jornada do herói, é a condição para o ritual final de iluminação.

0 beijo em Saul permite à personagem o encontro com sensações passadas, projetando-as no presente, podendo agora aceitá-las e as compreender. 0 efeito deste ato é o caminho para a integração através do enfrentamento dos sentimentos destrutivos, transformando-o em degraus para a iluminação.

É preciso beijar meu próprio medo, pensei, para que ele se torne meu amigo. Entreaberta a boca dele cheirava mal, os lábios cobertos de partículas purulentas, os dentes podres. Uma cara de louco, uma caar de miséria [...] é preciso ser capaz de amar meu nojo mais profundo para que ele me mostre onde eu serei inteiramente eu. (ABREU, 1993, p.190)

Este momento de vitória frente ao Minotauro interior é retribuído com a revelação do segredo contido dentro da poltrona de veludo verde, emblemática em toda a narrativa por conter no seu verde a esperança do encontro de algo além: o mapa do paradeiro de Dulce, um local no centro do país, a cidade de Estrela do Norte.

Este novo espaço representa nas etapas da jornada do Herói o 'Centro do Mundo', é o local de transcendência do espaço profano da cidade para se penetrar em uma região pura, rodeada pela mata, som de pássaros, um novo espaço, sacralizado, em que irá ocorrer o ritual de iluminação que possibilita tocar diretamente o sagrado. (ELIADE, 2002). Nesta geografia sagrada e mítica ocorre o 'encontro com a Deusa' depois de cumpridas todas as etapas da jornada labiríntica e vencido o Minotauro. Campbell (2004, p. 111) descreve este encontro como a "aventura última, quando todas as barreiras e ogros foram vencidos, costuma ser representado como casamento místico (hiérogamos) da alma do herói triunfante com a Rainha-Deusa do Mundo. [...] no canto mais extremo da Terra, no ponto central do cosmo".

A música é o fio condutor e prelúdio final para o encontro libertador com Dulce:a voz não muito longe, acompanhada das notas de um piano, desfazem a estranheza do novo espaço, em Estrela do Norte, no centro do Brasil, onde a personagem culmina sua busca. A voz o leva a uma churrascaria, em que encontra Dulce. Seu nome representa a doçura e o acalanto retratados na figura da mãe mitológica universal. Eleacompanha-a em uma caminhada descalço que permite um contato mais íntimo com a terra, cada vez mais sendo envolvido por este espaço sagrado, recebendo suas energias. 
Na casa de Dulce inicia-se um processo de purificação e benção através rituais diversos: inicialmente ela lhe oferece um chá e neste gesto se abrigam as memórias de aconchego maternal que contrasta com o gosto amargo. Recebe das mãos de Dulce a consagração do batismo que representa a entrada em uma nova vida, e uma massagem que desata os nós espirituais que se somatizaram em seu corpo. Esse ritual o leva a uma espécie de sono. Ao despertar, a meia noite, é seu aniversário e acontece o final do ritual de purificação.

Inicialmente passa por uma espécie de metamorfose: "percebi que meu corpo estava enredado em fios cinzentos, eu quase não podia andar [...] levei muito tempo até conseguir tirá-las de mim" (ABREU, 1993, p. 207). Após sair do casulo, ele vomita, expurgando os últimos resquícios de impureza, tornando-se limpo e renovado.

Uma vez libertado de todas suas amarras existenciais ocorre a 'Apoteose', o momento de expansão da consciência, em que o herói se torna livre de seus temores (CAMPBELL, 2004). A apoteose ocorre no momento ritualístico da união com o Uno, esta união se dá em um espaço sagrado, no centro do mundo onde está presente a Árvore Cósmica, que liga os três mundos inferno, terra, céu. Seus sete galhos representam as sete esferas terrestres que simbolizam a ascensão ao céu. (ELIADE, 2002). Este momento espetacular é descrito em minúcias na narrativa:

\footnotetext{
era uma árvore. Encostei o corpo nela. Primeiro de costas, depois de frente. Circundei-a com os braços. Ela tremia, eu também. Eu abri minhas pernas, encostei meu sexo duro na sua casca áspera, depois a barriga, o peito, os ombros em arco, para melhor amoldá-la a mim. Eu encostei também o meu rosto, o topo da minha cabeça onde os cabelos começavam a fugir. 0 corpo da árvore recebia o meu corpo como corpo de uma pessoa recebe o corpo de outra, quando fazem amor. Além de sua casca áspera, havia um centro vazio que eu penetrava. Tremi com mais força de encontro a ela, e fiquei todo molhado. (ABREU, 1993, p. 209)
}

As imagens representam a transcendência, o momento em que o protagonista se torna uno, conectado aocosmos, libertando-se das barreiras do tempo, em que todos os fragmentos do passado se compõem numa unidade e sua identidade é recuperada: "Eu estava ali, onde eu deveria estar. Inteiro. Como uma gota de mercúrio." (ABREU, 1993, p.210)

O despertar da aurora anuncia o 'retorno', o herói recebe a 'benção última', um poder imperecível que possa levar consigo, algo que o herói possa ser digno de merecimento. É um símbolo de energia que permite ao herói caminhar rumo ao seu 
destino (CAMPBELL, 2004). A benção última que Dulce concede ao protagonista é representada por um presente, um gato, chamado Cazuza. 0 gato é uma figura que se sobrepõe ao tempo, por representar múltiplas existências, e o nome Cazuza finaliza a trajetória musical da narrativa, remetendo ao cantor que foi referência da cultura pop brasileira dos anos 80, marcando uma geração e transpassando a barreira do tempo, pois sua música ecoa nas vozes de diversos artistas da contemporaneidade.

A benção, o felino que acompanhará o protagonista na volta ao mundo urbano, representa a imortalidade do ser que se manifesta através da música, do homem que alcança a transcendência através do fio musical capaz de restaurar memórias, de expor sem véus a interioridade do indivíduo. Para fechar o ciclo da jornada do herói, a narrativa termina, com a frase: "E eu comecei a cantar." (ABREU, 1993, p. 213). Assim, a experiência vivida se traduz em um processo circular, capaz, no entanto, de romper com as noções de privação e ausência que marcavam o início da trajetória do protagonista. 0 sujeito adentrou múltiplos labirintos e, através dos fios da música e da memória, emergiu para a (re)construção de uma identidade a se integrar no seu complexo espaço e tempo.

\section{Referências}

ABREU, Caio Fernando. Onde andará Dulce Veiga? Um romance B. São Paulo: Companhia das Letras, 1990.

BACHELARD, G. A poética do espaço. São Paulo: Martins Fontes, 1993.

BAUMAN, Zygmunt. O mal-estar da pós-modernidade. Rio de Janeiro: Jorge Zahar Ed, 1998.

. Medo Líquido. Rio de Janeiro: Jorge Zahar. Ed, 2008.

Confiança e medo na cidade. Rio de Janeiro: Jorge Zahar. Ed, 2009.

BERMAN, Marshall. Tudo que é sólido desmancha no ar: a aventura da modernidade. São Paulo: Companhia das Letras, 1986.

BERND, Zilá (org.) Dicionário das mobilidades culturais: percursos americanos. Porto Alegre: Literalis, 2010.

BRUNEL, Pierre. Dicionário de mitos literários. Rio de Janeiro: José Olympio, 2005.

CAMPBELL, Joseph. O herói de mil faces. São Paulo: Cultrix, 2004. 
CHEVALIER, J.; GHEERBRANT, A. Dicionário de símbolos: mitos, sonhos,costumes, gestos, formas, figuras, cores, números. Rio de Janeiro: José Olympio, 2003.

DURAND, Gilbert. As estruturas antropológicas do imaginário. introdução à arquetipologia geral. Lisboa: Ed. Presença, 1989.

ELIADE, Mircea. Imagens e símbolos: ensaio sobre o simbolismo mágico-religioso. São Paulo: Martins Fontes, 2002.

FERREIRA, José Ribeiro. Labirinto e Minotauro: mito de ontem e hoje. Coleção Fluir Perene. Coimbra, 2008. (www.fluirperene.com/livros/labirinto e minotauro.pdf)

GOMES, Renato Cordeiro. Todas as cidades, a cidade: literatura e experiência urbana. Rio de Janeiro: Rocco, 2008.

HARVEY, David. Condição pós-moderna: uma pesquisa sobre as origens da mudança cultural. São Paulo: Edições Loyola, 1998.

LEAL, Bruno de Souza. Caio Fernando Abreu, a metrópole e a paixão do estrangeiro: contos, identidade e sexualidade em trânsito. São Paulo: Annablume, 2002.

PORTO, Maria Bernadete. Circulações urbanas. In: BERND, Zilá (org.) Dicionário das mobilidades culturais: percursos americanos. Porto Alegre: Literalis, 2010.

Recebido em março de 2014.

Aceito em junho de 2014. 